\title{
On Some Phytometers of Seasonal Winds
}

\section{K. MisawA*}

(1) Impossibility of Inferrence of Prevailing Wind at a Locality from Observations at Wetached Meteorological Stations.

As will be illustrated from the following actual example as deduced from the observations by means of phytometer method, the winds are so much influenced even by a minute configuration of topography, that we cannot even infer the direction of the wind at a locality from the observational data at detached meteorological stations, even. with a density of one station per 3000 4000 $\mathrm{km}^{2}$. as is really the case in Japan. Fig. 1 shows

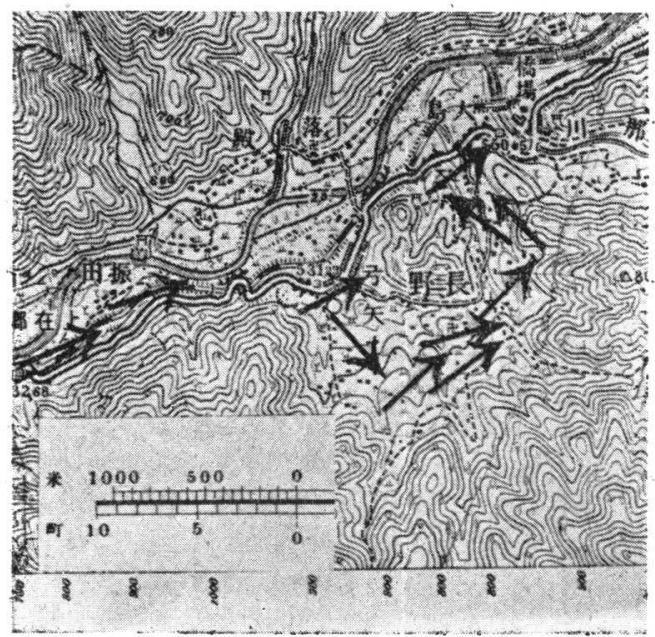

Fig. 1. The bending directions of persimmon trees around a tiny hill named Sekiyama at Suhara Nillage, Nishichikuma Province, Nagano Prefecture.

the modification of the direction of the prevailing wind in early summer by a tiny hill with relative height and horizontal extension not exceeding $100 \mathrm{~m}$. and $500 \mathrm{~m}$. respectively. ${ }^{1)}$ The successive article is another example of the winds of early summer which have blown up the valleys of Tenryugawa and Kamanashigawa from the Pacific coast, and make almost at right angles over Lake Suwa, the former continuing to blow further northbeyond the Shioziri Pass. 2)

In view of these delicate modifications of the wind by topographical features, and difficulty of establishing sufficient number of meteorological stations, we shall be at a loss if we connot find other means of inferring the directions, strength and persistence of seasonal winds. I shall next describe some phytometers for prevailing winds

* 1885-1937

** the Compiler

\section{\& H.MisawA**}

in various seasons which I found useful in Nagano Prefecture.

(2) Some Phytometers of Seasonal Winds and Actual Observations thereby.

It has already been long since the characteristic shapes of trees and grasses bent by winds at seaside as well as at summit areas of high mountains has been noticed and studied by many dendrologists. The object of their studies, however, was restricted to stonger winds, so that until at present, they have no clue to infer weaker winds in question. It was more than a quarter of a century ago that I noticed the strange deformations of persimmon trees in the Suwa district. $\left.{ }^{3} 4\right)$

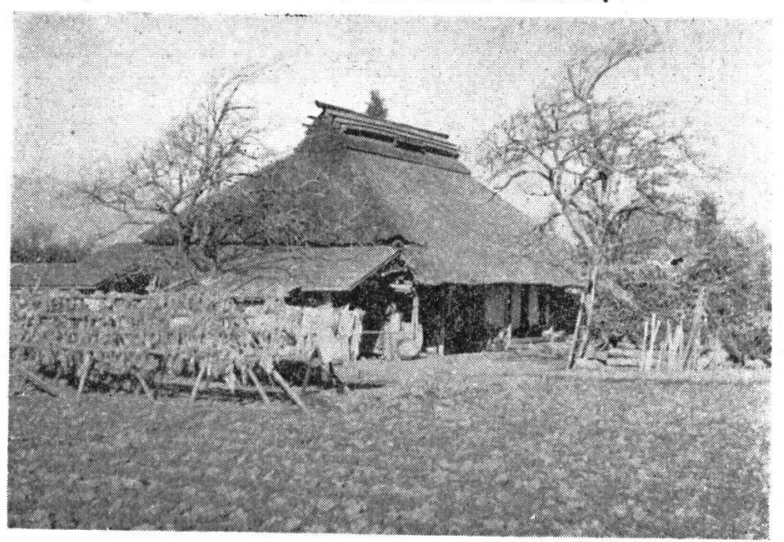

Fig. 2. The persimmon trees bended by the south westerly seasonal winds in summer at Misuzu Village, Kamiina Country, Nagano Prefecture (撮影者向山雅重氏)

The bending of some of these trees was so remarkable that not only the branches but also that the boughs and sometimes even the trunk itself was bent as shown in Fig. 2. While on the contrary there were lots of persimmon trees whose twigs and branches seemed to extend at random in all directions. In such trees at first I could find neither bendings of branches nor the deformations of even things. Closer examinations, however, revealed the slight bendings of a few twigs at their top-ends. I then drew the wind roses of each month based upon the observation at the Fujimi Meteorological Staion, the Bureau of Forestry and compared them with the bending directions of the persimmon trees at the locality, with the result that the bendings of these twigs were found parallel to the prevailing directions of the seasonal winds in summer. Soon after this I found that the rice plants were also bent opposite to the prevailing directions of the seasonal winds in autumn, while the reeds in winter were found to be service- 
able to handy windvanes. Hence with my clinometer I continued to measure thousands of persimmon trees and drew the directions of these bendings on the maps of the scale $1: 50,000$. I thus recognized that the twigs of the persimmon trees were so sensitive as to be bent even by very weak winds in early summer. If the winds are weak, the bendings are limited only to the top-ends, and the stronger the winds are, the branches and the boughs are also bent. The locality where the trunk itself is also bent was found to be the region of the strongest winds. It is to be noted that the trees in the locality with no prevalent direction of wind in early summer extend their branches at random in all directions.

In 1939, Dr. H. Kawasumi, Professor of Seismology, the Seismological Institute attached to the

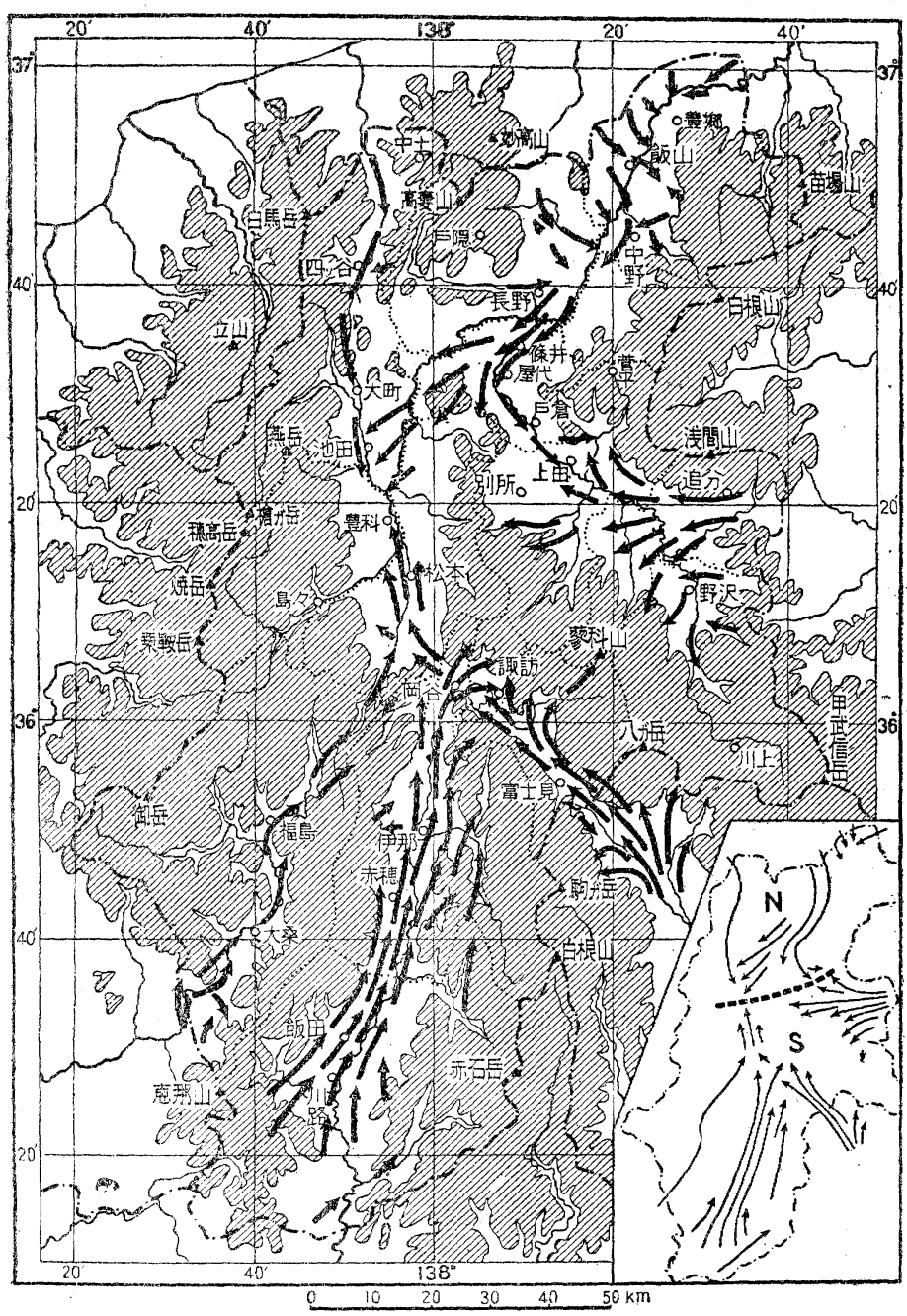

Fig. 3 The seasonal winds in summer over Nagano Prefecture
Tokyo University drew the wind roses at $7 \mathrm{Me}$ teorological Stations in Nagano Prefecture and compared them with the bending directions of the persimmon trees measured by the author at these localities with the result that they all showed splendid coincidences with each other to re-affirm the above statement. 5 )

Now the synthesized result of my long years' observations is shown in Fig. 3 .

It is a matter of convenience for us that the persimmon trees are so extensively planted all over Japan Proper except in Hokkaido, while reeds are one of the plants renowned for their widest distribution throughout the world except in the Ama $z o n$. And needless to say, rice piants are so well cultivated that they occupy half of the tilled land in Japan. But my research is ro more than incipient, so that it is my earnest desire to persue this study not only over Nagano Prefecture but also, at least, over all of Japan Proper, and draw numerous wind roses at every meteorological station in Japan in order to compare them with the bending direction of these phytometers at every corresponding locality, and inquire into the mechanism of the bending of these plants physiologically.

\section{Literatures}

(1) After Mr. Takeshi Sekiguchi's calculation.

(2) Misawa, K. and Misawa, $H$. On the Seasonal Winds it Summer over and around the Suwa Basin (umpublished).

(3) Misawa, Katsue. Geographical Review Vol. 5 No. 9 (1929) (in Japanese)

(4) Misawa, K. Fudosangyo (Maximum Utilization of a Unit Area) 3 rd Ed. (1952)

(5) Misawa, K, and Kawasumi, $H$. Geography Vol. 7 pp. 1131-1143 and 1398-1396 (1939) (in Japanese)

\section{概 要}

常風向は微細なる地形地物の影響を鋭 敏に蒙り，いずれの地点の常風向も機械 観測の久によつて推定するには現在の施 設はあまりに政柬である。ところが柿及 び稻の傾曲景はそれぞれ夏李及び秋季の 常風向を示し，萌及びススキの穂の傾き は冬李の風を推定するのに存力なること を知つた。よつて小文ではその一例とし 長野県汇护方夏季常風向图を揭げた。 特に今回悻筆者の求に快く泣じすばらし き写真を撮影して下さつた向山雅電氏に 裹心の御礼を埥上泊たい。 